\title{
EHF wt Allele
}

National Cancer Institute

\section{Source}

National Cancer Institute. EHF wt Allele. NCI Thesaurus. Code C52539.

Human EHF wild-type allele is located in the vicinity of $11 \mathrm{p} 12$ and is approximately $40 \mathrm{~kb}$ in length. This allele, which encodes ETS homologous factor protein, plays a role in both transcriptional regulation and cell differentiation. 